\title{
Seçilen Büyükşehir Belediyelerinin Engelli İstihdamına Yönelik Faaliyetlerinin Fırsat Eşitliği Açısından Değerlendirilmesi a
}

Süheyla Erikliib,c

Özet

Anayasanın 2. maddesinde belirtildiği üzere "Türkiye Cumhuriyeti sosyal bir hukuk devletidir." Sosyal devlet kavramı bireyin yalnızca hukuk önünde eşit olmasına değil; bireyin sosyal ve ekonomik fırsatlara sahip olmadaki eşitliğine de vurgu yapmaktadır. Sosyal devlet anlayışının yerel yönetimlerdeki temsilcisi ise sosyal belediyecilik anlayışına göre hizmet veren belediyelerdir. 2005 yılında kabul edilen 5378 Sayılı Engelliler Hakkında Kanuna 2014 yılında eklenen 14.maddede belirtildiği üzere devlet engelli bireylerin işgücüne katılması ve çalışma ortamında kalıcı olması için gerekli tedbirler almakla yükümlüdür. 2004 yılında yürürlüğe giren 5216 sayılı Büyükşehir Belediyesi Kanunun 7.maddesinde ise Büyükşehir Belediyelerine, engellilere yönelik olarak meslek ve beceri kazandırmaya yönelik kursları açmak ve bu hizmetleri yürütürken üniversiteler, yüksek okullar, meslek liseleri, kamu kuruluşları ve sivil toplum örgütleri ile işbirliği yapmak görevi verilmiştir.

Bu çalışmada Ankara, İstanbul, Antalya ve 2012 yılında Büyükşehir Belediyesi statüsü kazanan iller içerisinde en fazla nüfusa sahip olan Şanlıurfa, Hatay ve Trabzon büyükşehir belediyelerinin 2018 yılı faaliyet raporları incelenerek, engellilere yönelik uygulanan politikalar değerlendirilmektedir.
Anahtar Kelimeler

Sosyal Devlet

Sosyal Adalet

Engellilik Hali

Fırsat Eşitliği

Makale Hakkında

Geliş Tarihi: 27.07.2019

Kabul Tarihi: 12.10 .2020

Doi: $10.18026 /$ cbayarsos.597547

\section{The Evaluation By "Equal Opportunities" of Policies To Accessing The Employment Of Disabled People}

\begin{abstract}
The Republic of Turkey is a social law state. Social state emphasizes not only the equality of individiual by laws but also social and economic opportunities. Municipalites are a unit of the sociak state in local government. So, Its are obliged to provide interpersonal equal oppurtinity. The Disability Law No. 5378 was adopted in 2005. With the regulation in 2014, the area of responsibility of Municipalities has increased. To be more clear, its have to engage in activities the infrastructure as well as social municipality activities. For example hold vocational training and development a course, do social and cultural activity etc.

In this study is examined the annual reports of the Metropolitan municipalities of Ankara, İstanbul and Antalya as well as Sanliurfa, Hatay and Trabzon, which gained Metropolitan Municipality status in 2012. Then, it is evaluated that whether there is a unity of practice among the provinces by policies for the disabled in annual reports.
\end{abstract}

Keywords

Social State

Social Justice

Disability

Equality of Opportunity

About Article

Received: 27.07.2019

Accepted: 12.10.2020

Doi: 10.18026/cbayarsos.597547

\footnotetext{
a Bu çalışma, TAEM Uluslararası Sosyal Politikalar Kongresi'nde (2019) sunulan "Engellilerin İstihdama Erişimine Yönelik Uygulanan Politikaların

"Eşit Fırsatlar" Açısından Değerlendirilmesi" adlı tebliğin geliştirilmesiyle elde edilmiştir.

b İletişim Yazarı: serikli@ybu.edu.tr

c Dr.Ögr.Üyesi, Ankara Yıldırım Beyazıt Üniversitesi, ORCID: 0000-0002-5817-6469
} 


\section{Giriş}

Türkiye genelinde engelli bireylerin sayısını tahmin eden son araştırma Türkiye İstatistik Kurumu (TÜIK) tarafından gerçekleştirilen "2011 Nüfus ve Konut Araştırmasıdır." Araştırmaya göre en az bir fonksiyonda zorlandığını belirten kişi sayısı 4 milyon 882 bin 841'dir. Buna göre 2011 yılında toplam nüfusun \%6,6'sının en az bir engeli bulunmaktadır. Engelli nüfus içinde engel grubu incelendiğinde en yüksek oran sirasılla "bir şeyler taşımada/tutmada zorluk yaşayanlar $(\% 4,1)$ ", "yürümede, merdiven çıkmada/inmede zorluk yaşayanlar $(\% 3,3)$ ", “yaşıtlarına göre öğrenmede zorluk yaşayanlar (\%2)," dır (www.ailevecalisma.gov.tr $)^{\S}$.

TÜİK'in Özürlüler İdaresi Başkanlığı ile yapılan protokol kapsamında, 2010 yılında gerçekleştirdiği Özürlülerin Sorun ve Beklentileri Araştırması sonuçlarına göre ise toplam engellilerin \%28,7'si iş bulma olanaklarının arttırılmasını kamu kurum ve kuruluşlarından talep ederken; görme engellilerde bu oranın $\% 45,5^{\prime} \mathrm{e}$, işitme engellilerde ise $\% 43,5^{\prime}$ e yükseldiğ görülmektedir (www.ailevecalisma.gov.tr). Engelli bireyler için istihdamda yer almak, toplum ile kaynaşmalarını ve kendilerini topluma değer katan bir birey olarak hissetmelerini sağlamaktadır. Dolayısıyla çalışma, engelli bireylerin hissedebilecekleri toplumdan dışlanma hissinin azalmasını ve yenmesini sağlayarak bireyin sosyal ve psikolojik ihtiyaçlarını gideren bir işleve sahiptir (ASPB, 2015, s. 34).

Belediyeler vatandaşlara hizmet sunan en yakın kamu kurumu olmaları sebebiyle sosyal politikaların uygulanmasında önemli bir role sahiptirler. Özellikle 2014 ve 2015 yılında Belediye ve Büyükşehir Belediye Kanununda yapılan düzenlemeler ile belediyelerin sorumluluk alanları genişletilmiş; belediyelere alt yapı hizmetlerinin yanı sıra sosyal hizmet sağlama sorumluluğu verilmiştir. Her ne kadar işgücü piyasası konusunda sorumlu birim Türkiye İş Kurumu olsa da belediyelerin engellilerin istihdam edilebilirliklerini arttırmaya yönelik faaliyetlerde bulunmasını, sosyal belediyecilik anlayışının bir gereği olarak değerlendirmek mümkündür. Öte yandan ülke genelinde, belediyelerin uyguladıkları hizmetlerin benzer niteliklere ve içeriklere sahip olması "fırsat eşitliği" açısından önem taşımaktadır. Bir diğer ifade ile örneğin İstanbul Büyükş̧ehir Belediyesinin engelli bireylerin istihdam edilebilirliğini arttırmaya yönelik faaliyetleri ile Mardin Büyükşehir Belediyesinin sunmuş olduğu hizmetlerin benzerlik taşıması; bölgeler ya da illerden kaynaklı bir dezavantajlılık durumunun önüne geçecektir.

\section{Engelli Kavramı}

Engellilik durumuna ilişkin literatür incelendiğinde sakatlılık, özürlülük ve engellilik kavramlarının birbiri yerine kullanıldığı görülmektedir. Bu kavramları kısaca tanımlamak gerekirse sakatlık; kişinin fonksiyonel kayıplarını, özürlülük ise kişinin “özrünün normal günlük yaşam aktivitelerini ne kadar etkilediği" durumuna odaklanmaktadır. Sakatlık ile engellilik arasındaki fark ise engelliliğin çevresel faktörlere odaklanmasıdır. Daha açık ifade etmek gerekirse herkesin bir sakatlığı olabilir ve fakat söz konusu sakatlık çevresel engeller

\footnotetext{
§ Engelli birey sayısının tespit edilmesi amacıyla Aile, Çalışma ve Sosyal Hizmet Bakanlı̆̆ bünyesinde kamu kurum ve kuruluşlarındaki Engelli Sağlık Kurulu Raporlarını temel alan “Ulusal Engelli Veri Sistemi” oluşturulmuştur. 2020 yılı mart a yına göre sistemde kayıtlı ve hayatta olan engelli sayısı 2.533.209'dur (Engelli ve Yaşlı İstatistik Bülteni, 2020).
} 
nedeniyle engellilik haline dönüşmektedir. Örneğin Birleşik Krallıkta gözleri iyi görmeyen bir birey gözlük kullanarak kendini engelli hissetmez veya öyle görmez iken, kırsal Afrika'da aynı durumdaki bir birey oftalmik bakıma erişemediği için başta eğitim olmak üzere kamusal pek çok hizmete erişimde zorlukla karşılaşacaktır. Dolayısıyla çevresel faktörler sakat bireyin engelli birey haline dönüşmesine yol açacaktır (Köten ve Erdoğan, 2014, s.24).

Ayrımcılığa Karşı Fiziksel Yeti Yitimi Olanların Birliği (Union of the Physicall Imparied Against Segregation) sakatlık kavramını toplumsal alana yönlendiren önemli bir bildiri yayınlamışlardır. Bildiride sakatlık durumunu; yeti yitimi olan insanları dikkate almayan ya da çok az dikkate alan ve dolayısıyla genelin katıldığı toplumsal faaliyetlerden dişlayan çağdaş bir toplumsal düzenin yol açtığı hareket kısıtlaması veya bir dezavantaj olarak tanımlamışlardır (Thomas, 2002, s. 32).

Finkelstein sakatlık durumunu tarihsel süreç açısından üç aşamalı olarak ele almıştır; Birinci aşama feodal topluma, ikinci aşama çalışmanın evden sanayiye geçtiği sanayileşme ve kapitalistleşme sürecine ve üçüncü aşama ise içerisinde bulunduğumuz sürece tekabül etmektedir. Birinci aşamada yoğunlukla tarım toplumuna dayanan ekonomik yapı her bir bireyin üretim sürecine dahil olmasına olanak sağlamaktaydı. Bu dönemde sakat bireyler talihsiz olarak değerlendirilmelerine rağmen toplumdan dışlanmıyorlardı. İkinci aşamada fabrikanın ortaya çıkması ile birlikte büyük bir engelli kitlesinin üretim sürecinden dışlanması söz konusu oldu; çünkü fabrika üretiminin çalışmanın hızı, disiplini ve üretim normları engelli bireyler için uygun değildi. Üçüncü aşamada ise engelli bireylerin yeni teknolojilerden faydalanması ile engelli bireylerin engelli olmayan bireyler ile işbirliği yapmalarına olanak sağlayarak engelli bireylerin toplumdan dişlanma durumunun olmayacağı öngörülmektedir (Oliver,1990, s. 210-211). Tarihsel sürecin ikinci aşamasında yer aldığımızdan hareketle Finkelstein sakatlık durumunu, bireyin durumu (yeti yitimi) ile toplumun bireye dayattığ sinırlılıkları içeren bir paradoks olarak tanımlamıştır (Oliver,1990, s.211).

Engelliliği açıklamada alternatif yaklaşım olarak ortaya çıkan insan çeşitliliği modeli ise sakatlığ mevcut kurumlar bir toplumda gerçekte olduğundan çok daha sınırlı bir insan çeşitliliğiyle uğraşmak için inşa edilmiştir (Schiner, 2001, s. 270).

Engellilik tanımının yasal mevzuatta nasıl ele alındığ tarafından 1975 yılında kabul edilen Engelli Hakları Beyannamesi'nde; "bireylerin normal hayatlarında yapageldikleri işleri doğuştan veya daha sonra bir kaza sebebiyle oluşan noksanlık sonucunda yapamamaları durumu" olarak tanımlandığı görülmektedir. Uluslararası Çalışma Örgütü (ILO,1983) engellilik durumunu 159 numaralı Mesleki Rehabilitasyon ve İstihdam (Sakatlar) sözleşmesinde, "Bir işin temini, muhafazası ve işinde ilerlemesi hususundaki beklentileri, kabul edilmiş fiziksel veya zihinsel özür sonucu önemli ölçüde azalmış birey" olarak tanımlamaktadır.

Birleşmiş Milletlerin 2006 yılında kabul ettiği, Türkiye'nin ise 2008 yılında imzaladığı Engellilerin Haklarına İlişkin Sözleşme' de engellilik, "diğer bireylerle aynı şartlar altında olup da fiziksel, zihinsel, algisal ya da düşünsel bozukluğu nedeniyle topluma eşit ve etkin bir şekilde katılamayan kişiler" olarak tanımlanmaktadır (Milletlerarası Sözleşme, 2009). 
01.07.2005 tarihli 5378 Sayılı Engelliler ve Bazı Kanun ve Kanun Huikmünde Kararnamelerde Değişiklik Yapılması Hakkındaki Kanun ve 2006 yılında çıkartılan Büyükşehir Belediyeleri Özürlü Hizmetleri Birimleri Yönetmeliğine göre engelli; “doğuştan veya daha sonra çeşitli nedenlerle bedensel, zihinsel, sosyal, ruhsal ve duygusal yeti ve yeteneklerini belli oranda kaybetmesi sonucunda topluma ve toplumsal yaşama uyum sağlamada ve günluk gereksinimlerini karşılamada güçlikleri olan ve bu nedenle korunma, bakım, rehabilitasyon, danışmanlık ve destek hizmetlerine ihtiyaç duyan kişi" olarak tanımlanmıştır.

\section{Engelli Bireylere Sosyal Politika Açısından Bakış: Fırsat Eşitliği}

Engellilik konusu geleneksel politika yaklaşımına göre kişiye özel bir sorun olarak algılanarak bir bakım veya rehabilitasyon sorunu olarak değerlendirilmekte iken; günümüzde bu sorun bireysel (fiziksel) nedenlere değil, toplumdaki engelliliklere dayandırılmaktadır (Priestley, 2011, s. 522). Bu bakış açısı engellilik ile ayrımcılık arasında yakın bir bağ kurmaktadır. Bir diğer ifade ile sorun, bireyin "özürlü olma halinden" toplumsal ve çevresel "engellere" kaymış; kişisel ön yargılar, ulaşım sistemi ve eğitim alanından istihdam alanına kadar pek çok konudaki yetersizlikler bu kişilerin sosyal yaşama katılımını engelleyerek ayrımcılık sorununu ortaya çıkartmıştır. Söz konusu bakış açısı engellilere yönelik sosyal politika düzenlemelerinin önemini arttırmıştır. Sosyal politikalar toplumda eşitsizliğe uğrayan gruplar arasında fırsat eşitliği sağlamaya yönelik politikalar üretmektedir (Koray, 2000, s.208). Sosyal politikanın engelli bireylere ilişkin politikalar üretmesinin sebebi "sosyal adalet" amacı taşıması ile ilgilidir (Koray, 2000, s. 11). Sosyal adalet ilkesi toplumda aynı kuşağı oluşturan insanların sosyal statü kazanmada ve sosyal risklerle karşılaşmada eşit şanslara ve risklere sahip olmasıdır. Hakların kullanılması bakımından dezavantajlı grupları, dezavantajlı olmayan gruplar ile denkleştirmek amacı ile devletin, hukukun ve sivil toplum kuruluşlarının pozitif bir yükümlülüğü bulunmaktadır. Bu yükümlülük sadece bir koruma yükümlülüğü değil; aynı zamanda hakların nesnelleştirmesi ve dezavantajların giderilmesi ve adaletin sağlanması ile ilgilidir (Göregenli, 2008,s. 14). Dolayısıyla sosyal politika, sosyal adalet misyonunun doğal bir sonucu olarak bir toplumda bireye, insan onuruna yaraşır asgari hayat standardının garanti etmeyi hedeflemektedir (Başbuğ, 2013,s.11).

Sosyal adaletin sağlanması ise fırsat eşitliğinin sağlanması ile gerçekleşmektedir (Güven, 1995, s.21). Engellilerin istihdama erişebilmesi için öncelikle fırsat eşitliğinin sağlanması gerekmektedir. Fırsat eşitliği kişilerin yarışmaya başlamadan önce, doğal ve sosyal şartlardan kaynaklanan her türlü avantaj ve dezavantajların ortadan kaldırılmasıdır, böylece herkes yarışa aynı noktadan başlayabilir (Ertürk, 2018,s. 22).

Fırsat eşitliği kavramı şekli eşitlik uygulamalarının yetersiz kalması sonucunda ortaya çıkmıştır. Daha açık ifade etmek gerekirse modern toplumun ortaya koyduğu modern hukuk, tüm bireyleri eşit niteliklere sahip varlıklar olarak tanımlamaktadır (Göregenli, 2012, s.19). Şekli eşitlik ya da kanun önünde eşitlik olarak kategorize edilen bu yaklaşım herkesin doğuştan eşit olduğunu varsayarak ayrımcılık yapılmadığı sürece herkesin eşit olduğunu kabul etmektedir. Ancak kanun önünde herkesin eşit olduğuna ilişkin yaklaşım, toplum 
içerisinde dezavantajlı konumda bulunan insanlara yönelik özel önlemler ve sosyal politikalar oluşturmasını içermediği için eşit bir toplum yaratmaya yetmemiştir. Bu durum maddi eşitlik ihtiyacı yaratmıştır. Maddi eşitlik anlayışı kişiler arasında cinsiyet, yaş, engellilik durumu vb. durumlara bağlı olarak farklılıklar olduğunu, bu nedenle mevcut eşitsizlikleri gidermek için geçici özel önlemler alınması gerektiğini savunmaktadır (Gül ve Karan, 2011, s. 6-7).

Engelli hakları ve engelli istihdamına yönelik sosyal politika düzenlemelerinin temel dayanak noktasını uluslararası sözleşmeler oluşturmaktadır. Örneğin Birleşmiş Milletler (BM) 1975 tarihli Engelli Kişilerin Hakları Bildirgesinde (EKHB) ile engellilik insan hakları sorunu olarak tanımlanmıştır. EKHB, engelli kişilerin engelli olmayan bireyler ile eşit haklara sahip olduklarını vurgulayarak doğrudan ayrımcılığı yasaklamanın yanı sıra, engelli kişilerin tedavi, bakım ve rehabilitasyon hizmetleri alma haklarını düzenlemekte ve eğitim, iş ve yargılama gibi alanlarda eşit muamelenin gerçekleşebilmesi için gerekli pozitif tedbirlerin alınmasını öngörmektedir (Özürluilüge Dayalı Ayrımcılığın Ölçuilmesi Araştırması, 2010: 29). Uluslararası Çalışma Örgütü (ILO), BM'in 1981 yılını Tam Katılım ve Eşitlik" konusu ile söz konusu yılı Uluslararası Sakatlar Yılı ilan etmesi sonucu 1983 yılında 159 No'lu Mesleki Rehabilitasyon ve İstihdam Sözleşmesini kabul etmiştir. Türkiye'de 2000 yılında yürürlüğe giren Sözleşmenin 4.maddesinde Sakatlar İçin Mesleki Rehabilitasyon ve İstihdam Politikası Prensiplerinin fırsat eşitliği ilkesi üzerine kurulduğu ifade edilmiştir (www.ilo.org).

Engellilik konusunda bağlayıcı nitelikteki ilk ve tek uluslararası belge olan Birleşmiş Milletler Engelli Hakları Sözleşmesi sosyal politika açısından önem taşıyan bir diğer uluslararası sözleşmedir. Türkiye'nin en erken imzalayan ülkeler arasında yer aldığı sözleşme ülkemizde 3 mayıs 2008'de yürürlüğe girmiştir. Sözleşmede engellilik konusunda, hak temelli bir yaklaşımın benimsendiği görülmektedir. Yaklaşım; engelli kişileri yardımseverlik, tedavibakım veya sosyal himaye pratiklerinin nesneleri olarak görmek yerine, haklara sahip özneler olarak görmektedir. Engelli kişiler, bu hakları ileri sürebilen ve kendi yaşamları konusunda karar alabilen, toplumlarının aktif üyeleri olarak görulmektedir (Özürluilüge Dayalı Ayrımcılığın Ölçuilmesi Araştırması, 2010, s.30).

\section{Engellilerin Çalışma Hakkı ve Türkiye'de Engellilerin Çalışma Yaşamına Katılımına Yönelik Uygulanan Yöntemler}

Türkiye'de 1982 yılında kabul edilen Anayasasının üçüncü bölümü Sosyal ve Ekonomik Haklar ve Ödevler başlı̆̆ı taşımaktadır. Bu bölümün içerisinde yer alan 49. madde Çalışma Hakkı ve Ödevini düzenlemiştir. Söz konusu maddeye göre "Çalışma, herkesin hakkı ve ödevidir". Diğer yandan 49. maddeye 2001 yılında eklenen madde ile "Devlet, çalışanların hayat seviyesini yükseltmek, çalışma hayatını geliştirmek için çalışanları ve ișsizleri korumak, çalışmayı desteklemek, işsizliği önlemeye elverişli ekonomik bir ortam yaratmak ve çalışma barışını sağlamak için gerekli tedbirleri alır." ibaresi eklenmiştir. Yine Anayasanın 50. maddesinin 2. fıkrasında, bedenî veya ruhî yetersizliği olanların çalışma şartları bakımından özel olarak korunacakları öngörülmüştür.

2010 yılında Anayasanın 10. maddesinde yapılan değişiklik sonucunda "Devlet, bireyler arasında eşitliği sağlamakla yükümlü olmakla birlikte bu eşitliği sağlamaya yönelik çocuklar, yaşlılar, özürlüler, harp ve vazife şehitlerinin dul ve yetimleri ile malul ve gaziler için alınacak 
tedbirlerin eşitlik ilkesine aykırı olarak yorumlanamayacağı" ifade edilmiştir. Bu düzenleme ile pozitif ayrımcılık anlayışı anayasal düzeyde kabul edilmiştir.

Ulusal mevzuatta engelli istihdamına yönelik çok sayıda yasal düzenleme olduğu görülmektedir. Bunlar; 1967 tarihli Deniz İş Kanunu, 1965 tarihli Devlet Memurları Kanunu, 1986 tarihli Mesleki Eğitim Kanunu, 1964 tarihli Sosyal Sigortalar Kanunu, 1994 tarihli Özelleştirme Uygulamaları Hakkında Kanun, 2006 tarihli Kamu Kurum ve Kuruluşlarında İşçi Olarak İstihdam Edilecek Özürlü ve Eski Hükümlülere Uygulanacak Sınav Yönetmeliği, 2003 tarihli Özürlü ve Eski Hükümlü Çalıştırmayan İşverenlerden Ceza Olarak Kesilen Paraları Kullanmaya Yetkili Komisyonun Kuruluşu ile Çalışması Usul ve Esasları Hakkında Yönetmelik, 2004 tarihli Özürlülerin Devlet Memurluğuna Alınma Şartları ile Yapılacak Yarışma Sınavları Hakkında Yönetmelik, 2004 tarihli Özürlü, Eski Hükümlü ve Terör Mağduru Hakkında Yönetmelik, 2006 tarihli Özel Mesleki Rehabilitasyon Merkezleri Hakkında Yönetmelik, 2005 tarihli Özürlülerin İstihdam Yılı Konulu 2004/28 sayılı Başbakanlık Genelgesi, 2006 tarihli Özürlülerin İstihdamı Hakkındaki 2006/15 sayılı Başbakanlık Genelgesi olarak siralanabilir (Orhan, 2013, s.33-34).

2005 yılında çıkarılan 5378 sayılı Engelliler Kanunun sosyal politika açısından önemli bir kırılma noktası oluşturduğunu ifade etmek gerekir**. Kanunun temel referans noktaları ayrımcılık yapmama, fırsat eşitliği ve sosyal hayatın bütün kademelerine tam katılım gibi ilkelerden oluşmaktadır. Bu kanun, engelliliğe biyolojik bozukluklar olarak ele alan "medikal model" temelinde yaklaşmak yerine hukukî, fizikî, meslekî ve sosyo-kültürel engelleri ortadan kaldıran bir "sosyal model" ortaya çıartarak paradigma değişimine yol açmıştır; Dolayısıyla sosyal model engelliliğe bir hastalık ya da kişisel bir sorun alanı olarak değerlendirmemekte; tam aksine engellilerin toplumsal hayata katılımların önündeki engellerin ortadan kaldırılması ile çözülecek bir sorun olarak ele almaktadır (Seyyar, 2008, s. 81). 2014 yılında 5378 sayılı kanunun 13. ve 14. maddesinde engellilerin istihdamına ilişkin düzenlemeler yapılmıştır. 13. maddede engellilerin meslek seçebilmesi ve bu alanda eğitim alabilmesi için devletin gerekli tedbirler alacağı ve bu amaç için C,alışma ve Sosyal Güvenlik Bakanlığ́, Millî Eğtim Bakanlığı, C,alışma ve Sosyal Güvenlik Bakanlığnca ve kamu kurum ve kuruluşları ile belediyeler ve diğer gerçek veya tüzel kișilerin sorumlu tutulduğu görülmektedir. 14 . maddede ise engellilerin istihdamına ilişkin devletin sorumlulukları belirtilmiştir.

Türkiye'de engelli bireylerin istihdamda yer alabilmesi için kullanılan yöntem kota sistemidir. Kota sistemi kapsamı dışında kalan işyerlerinde engelli istihdamının arttırılması içinse teşvikler uygulanmaktadır (www.media.iskur.gov.tr). Engelli istihdamını arttırmaya yönelik uygulanan yöntemler aşağıdaki şekilde sıralanabilir;

a) Kota yöntemi: Türkiye' de engellilere yönelik uygulanan ana istihdam yöntemi kota/ kotaceza yöntemidir ${ }^{+\dagger}$. Fiili eşitlik sağlanana kadar geçici özel önlemler almayı görev edinen sosyal devlet, kota uygulamaları ile özellikle cinsiyet ve engelli ayrımcılığı ile mücadele etmektedir. Örneğin 4857 sayılı İş Kanunun 30. maddesine göre; “İşverenler, elli veya daha fazla işçi çalıştırdıkları özel sektör iş yerlerinde yüzde üç özürlü, kamu iş yerlerinde

\footnotetext{
** Engelliler yasası sosyal politika açısında önem taşımaktadır. Söz konusu düzenlemenin refah devleti anlayışının sınırlarını genişleten bir özelliğe sahip olduğunu vurgulayanlar olduğu gibi düzenlemenin içeriğinin oldukça sınırlı bir kitleyi kapsadığını savunanlar da bulunmaktadır. Detaylı bilgi için bknz. Yılmaz, 2010. Boğaziçi Üniversitesi, Master tezi.

† Kota uygulamasına konu olan grubun sayısal olarak eksik veya yetersiz temsil edildiği anlayışından hareketle siyasal yaşam veya işgücü piyasasına katılım gibi çeşitli olanlarda asgari sayının belirlenmesidir.
} 
ise yüzde dört özürlü ve yüzde iki eski huikümlü işçiyi meslek, beden ve ruhi durumlarına uygun işlerde çalıştırmakla yuikümlüdürler." Ayrıca 657 sayılı Devlet Memurları Yasasına tabi olan kamu işyerlerinde de yüzde 3 oranında engelli istihdamı zorunlu tutulmuştur.

b) Korumalı işyeri modeli: Piyasadaki iş ortamlarına yönlendirilmesi görece zor olan engelliler için "korumalı işyeri" modeli uygulanmaktadır. Bunun için ilk olarak, sivil toplum kuruluşlarının, anılan engel gruplarının istihdamına yönelik detaylı projelerini İSKUR'a sunmaları ve tamamen piyasa şartlarına göre üretim, satış, pazarlama sürelerini sürdürmeleri gerekmektedir.Örneğin Ankara'da "Cafe Down Projesi" ile okul eğitimlerini ve kuruluş içi rehabilitasyon çalışmalarını kapasitesi ölçüsünde başarı ile tamamlamış, görev ve sorumluluk bilinci kazanmış engelli bireylerin istihdamı hedeflenmiştir.

c) Korumalı istihdam modeli: Devlet tarafından teknik ve mali yönden desteklenen ve çalışma ortamı özel olarak düzenlenen işyerlerinde gerçekleştirilmektedir. Engellilere yönelik uygulanan işgücü piyasası programları ve alınan tüm önlemlere ek olarak, engelli istihdamının teşvik edilmesi bakımından kota kapsamında çalıştırılan engellilerle, kontenjan fazlası engelli çalıştıran, yuikümlü olmadıkları halde engelli çalıştıran işverenlerin sigorta ödemelerine devlet yardımcı olmaktadır.

d) Prim teşviki: 2008 yılından itibaren uygulanan "prim teşviki" ile özel sektör işverenlerine, istihdam ettikleri her bir engelli için sigortalının prime esas kazanç alt sınırı üzerinden hesaplanan sigorta primine ait işveren hisselerinin tamamı Hazine ve Maliye Bakanlığ 1 tarafından karşılanmaktadır. İşyerlerden teşvikten yararlanması için kota kapsamında olma koşulu aranmamaktadır.

e) İlave istihdam teşviki: "Çalışma Hayatında Milli Seferlik" kapsamında hayata geçirilen düzenleme ile işverenlerin 2020 yılı sonuna kadar bir önceki yılın sigortalı sayısının ortalamasına ilave olarak işe aldıkları her bir sigortalı için 12 ay süreyle teşvikten yararlanmaktadır. İstihdam ettikleri kişinin engelli olması durumunda teşvik süresi 18 ay olarak uygulanmaktadır.

\section{Sosyal Belediyecilik Kavramı ve Sosyal Belediyecilik Anlayışının Engelli İstihdamı Açısından Önemi}

Sosyal belediyecilik anlayışı belediyelere elektrik, su, doğalgaz gibi altyapı yatırımlarının yanı sıra kamu harcamalarını konut, sağlık, eğitim, istihdam ve kültürel faaliyet alanlarını kapsayacak şekilde sosyal amaca yönlendiren, işsizlere ve ihtiyaç sahiplerine sosyal yardım yapılmasına ilişkin planlama ve düzenleme işlevi yuikleyen bir modeldir (Akdoğan, 2002, s. 18-19).

Sosyal belediyecilik kavramını dar ve geniş anlamda olmak üzere iki şekilde tanımlamak mümkündür. Dar anlamda sosyal belediyecilik kavramının içeriği sosyal güvenlik, sosyal koruma ve sosyal refah hizmetleri olarak sınırlandırılmakta iken; geniş anlamda sosyal 
belediyecilik anlayışının görevleri şu şekilde sıralanabilir (Koray ve Temiz, 2014, s. 20-21);

a) Kentlerin ekonomik, sosyal ve kültürel gelişimi (alt yapı, istihdam yaratma, konut politikaları, kültürel merkezler)

b) Sosyal refahın gelişimi (yoksulluğun sosyal ve ekonomik etkilerinin azaltılması, sosyal koruma, sosyal hizmetler ve eşitlik politikaları)

c) Demokrasi kültürünün gelişimi (belediye faaliyetleri aracılığı ile sivil toplumun ve katılımcılığın teşviki)

d) Kentlerin çevresel gelişimi (yeşil kentlerin oluşturulması, çevrenin korunması vb.)

2000'li yılların başından itibaren yasal düzenlemelerde yer bulan sosyal belediyecilik anlayışı, sosyal devlet anlayışının yereldeki temsilcisi konumundadır. Bu açıdan belediyeler, engellilerin bir yandan yaşadıkları mekanda pratik hayatın düzenlenmesinden sorumlu iken; diğer yandan engellilerin ilk basamak olarak sorunlarını ilettikleri kurumlar olmaları nedeniyle önem taşımaktadırlar (Kesgin, 2014, s.12). Sosyal belediyecilik anlayışının misyonlarından biri bireylerin eşit şartlarda toplumsal yaşama katılmalarını sağlamak amacıyla dezavantajlı gruplara yönelik olarak birtakım pozitif ayrımcılık içeren uygulamaları ifade eden fırsat eşitliği sağlamaya yönelik hizmetlerde bulunmaktır (Keleş, 2008, s. 45).

Büyükşehirlerde sosyal belediyecilik uygulamalarının günümüzdeki yasal dayanağını 2004 yılında yürürlüğe giren 5216 sayılı Büyükşehir Belediyesi Kanunu ve 2005 yılında yürürlüğe giren 5393 sayılı Belediye Kanunu oluşturmaktadır. 5216 sayılı Büyükşehir Belediyesi Kanunu 7. maddesinde Büyükşehir ve ilçe belediyelere yetişkinler, yaşlılar, engelliler, kadınlar, gençler ve çocuklar gibi dezavantajlı gruplara yönelik her türlü sosyal ve kültürel hizmetleri yürütmek, meslek ve beceri kazandırma kursları açma görevi verilmiştir.

2005 yılında yürürlüğe giren 5393 sayılı Belediye Kanunun, Belediyenin Görev, Yetki ve Sorumluluklarının tanımlandığ 14 . maddesinde belediyelerin sosyal hizmet, sosyal yardım, mesleki ve beceri kazandırma, ekonominin ve ticaretin geliştirilmesine yönelik hizmet yapma görevi verilmiştir.

2005 yılında gerçekleştirilen 2. Özürlüler Şurasının teması Yerel Yönetimler ve Özürlüler olarak belirlenmiştir. Şurada engelli istihdamında yerel yönetimlerin de sorumlu tutulduğu kararlar Tablo 1'de gösterilmiştir.

Tablo 1. Engelli İstihdamında Yerel Yönetimin Sorumlulukları

\begin{tabular}{lllc}
\hline \multicolumn{2}{c}{ Şura Kararı } & Sorumlu kurumlar & Süre \\
\hline Korunmaya muhtaç engellilerin & Yerelyön, SHÇEK, & Sürekli \\
mesleki eğitimi, rehabilitasyonu, & Türkiye Iş Kur, & \\
istihdamı ve yaşamını devam & MEB,SB,STK,Öz.İd.Baş. & \\
ettirebilmesi için Sosyal Hizmetler & & \\
ve Çocuk Esirgeme Kurumu & & \\
tarafından kurumlar arası & & \\
koordinasyon sağlanmalıdır.
\end{tabular}




\begin{tabular}{|c|c|c|}
\hline Mesleki $\quad$ rehabilitasyon & Yerel yön, Türkiye & Sürekli \\
\hline $\begin{array}{l}\text { kurumsallaştırılmalı ve } \\
\text { yaygınlaştırılmalıdır. } \\
\text { kurumlar ve yerel yönetimler, bu } \\
\text { konuda sorumluluk üstlenmelidir }\end{array}$ & İş Kur, & \\
\hline $\begin{array}{l}\text { Meslek edindirme programlarının } \\
\text { etkin ve yaygın şekilde verilmesi } \\
\text { sağlanmalıdır. İstihdam kursları } \\
\text { illerin özelliklerine ve işgücü } \\
\text { piyasası ihtiyaçlarına göre } \\
\text { verilmelidir }\end{array}$ & $\begin{array}{l}\text { Yerel yön,SHÇEK, } \\
\text { Türkiye İş Kur, } \\
\text { MEB,SB,STK,Öz.İd.Baş } \\
\text { İçişleri bak. }\end{array}$ & Sürekli \\
\hline $\begin{array}{l}\text { Mesleki eğitim verilecek mekanlar } \\
\text { engelli grupların özellikleri ve } \\
\text { ihtiyaçlarına göre fiziksel } \\
\text { donanıma kavuşturulmalıdır. }\end{array}$ & Yerel yön. & Sürekli \\
\hline $\begin{array}{l}\text { Hiçbir eğitim almamış ve mesleki } \\
\text { bilgi ve deneyimi olmayan genç } \\
\text { engellilere hazırlanacak programla } \\
\text { mesleki eğitim verilerek iş becerisi } \\
\text { kazandırılmalıdır. }\end{array}$ & $\begin{array}{l}\text { Yerel yön, MEB, } \\
\text { Türkiye İş Kur. }\end{array}$ & Sürekli \\
\hline $\begin{array}{l}\text { Engellilere yönelik "uygun işe } \\
\text { uygun eleman" } \\
\text { oluşturulmalıdır. İş ve meslek } \\
\text { danışmanlığı hizmetinin tüm } \\
\text { illerde etkin bir şekilde } \\
\text { gerçekleştirilmesi sağlanmalıdır. }\end{array}$ & $\begin{array}{l}\text { Yerel yön, } \\
\text { Yükseköğretim kurulu, } \\
\text { Öz.İd.Baş. Türkiye İş } \\
\text { Kur. }\end{array}$ & Uzun vadede \\
\hline $\begin{array}{l}\text { İnternet ortamında engellilere } \\
\text { ilişkin bilgilerin yer alması suretiyle } \\
\text { işverenlerin engelliler hakkında } \\
\text { bilgi sahibi olması sağlanmalıdır. }\end{array}$ & $\begin{array}{l}\text { Yerel yön, Türkiye } \\
\text { İş.Kur.,STK }\end{array}$ & Sürekli \\
\hline $\begin{array}{l}\text { Yerel düzeyde, engellilere yönelik } \\
\text { meslek edindirme programlarının } \\
\text { belirlenebilmesi, istihdamı arttırıcı } \\
\text { projeler geliştirilebilmesi için başta } \\
\text { yerel yönetimler olmak üzere ilgili } \\
\text { tüm tarafların kapasitesini arttırıcı } \\
\text { çalışmalar yapılmalıdır. }\end{array}$ & $\begin{array}{l}\text { Yerel yön, Türkiye } \\
\text { İş.Kur., Öz.İd.Baş, MEB }\end{array}$ & Sürekli \\
\hline $\begin{array}{l}\text { Engelli bireylerin iş yaşamına } \\
\text { katılımları konusunda aileleri } \\
\text { bilgilendirilmeli, bunun için aile } \\
\text { eğitim } \\
\text { hazırlanmalıdır. }\end{array}$ & $\begin{array}{l}\text { Yerel yön, MEB, Radyo } \\
\text { Tel.Üst. Kur. Türkiye İş } \\
\text { Kur. Öz. İd. Baş.STK }\end{array}$ & Sürekli \\
\hline
\end{tabular}

Kaynak: 2. Özürlüler Şurası, Yerel Yönetimler ve Özürlüler Şura Kararları, 2005, s.13-20.

Engelli istihdamına ilişkin veriler iller bazında değerlendirildiğinde Ankara'da engelli istihdam etmek zorunda olan işyeri sayısının 1.316 olduğu görülmektedir. İlde 9.104 engelli 
istihdamda yer almakta iken, 1.668 açık kontenjan bulunmaktadır. İstanbul'da ise engelli istihdam etmek zorunda olan işyeri sayısı $4.939^{\prime}$ dur. Çalışan engelli sayısı ise $26.088^{\prime}$ dir. Dolayısıyla Türkiye genelinde istihdam edilen engelli sayısının yaklaşı \%23'ü İstanbul ilinde gerçekleşmektedir. Türkiye genelinde açık kontenjan sayısının yaklaşık \%36'sı İstanbul iline ait olup bu sayı 8.891'dir. Hatay'da 773, Şanlıurfa' da 781 ve Trabzon'da 583 engelli istihdam edilmektedir. Açık kontenjan sayısı Hatay'da 379, Şanlıurfa' da 78, Trabzon'da ise 163'dür.

Hiç şüphesiz aktif işgücü piyasası programlarının içerikleri ve yoğunlukları engelli bireylerin işgücü piyasasında hangi konumda olacaklarını şekillendirmede önemli bir faktördür. Örneğin yoğun olarak girişimcilik eğitiminin verildiği illerde engellilerin işgücü piyasasında kendi hesabına çalışan bireyler olarak yer almalarına yardımcı olmak amaçlanırken; yoğun olarak mesleki eğitimin verildiği illerde engelli bireylere meslek edindirme ve mesleki eğitimlerini geliştirerek istihdam edilebilirliklerini artırmak amaçlanmakta; yoğun olarak iş başı eğitimin verildiği illerde ise işsizlerin mesleki tecrübeye sahip olmaları ve teorik eğitim aldıkları mesleklerde uygulamayı görmeleri amaçlanmaktadır.

Tablo 3'de görüldüğü üzere, 2017 yılında Türkiye genelinde 508.851 engelli aktif işgücü piyasası programlarından yararlanmıştır. İncelenen her bir ilde ise en fazla işbaşı eğitim kurslarının açıldığı ve dolayısıyla en yoğun katılımın işbaşı eğitim programlarında olduğu görülmektedir. İkinci sırada, İstanbul ve Antalya illerinde girişimcilik kursu, diğer illerde mesleki eğitim kursu açılmıştır.

Tablo 3. Engellilere Yönelik Aktif İşgücü Piyasası Programları

\begin{tabular}{llllllll}
\hline & \multicolumn{2}{c}{ Toplam } & \multicolumn{2}{c}{ Mesleki eğitim } & \multicolumn{2}{c}{ Girişimcilik eğitim } & \multicolumn{2}{c}{ İşbaşı eğitim } \\
\cline { 2 - 8 } & Toplam sayı & Kurs & Katılan & Kurs & Katılan & Kurs & Katılan \\
\hline Ankara & 26.044 & 260 & 7.092 & 112 & 2.575 & 5.413 & 16.377 \\
\hline İstanbul & 59.259 & 344 & 6.279 & 555 & 16.833 & 10.830 & 36.147 \\
\hline Antalya & 29.014 & 67 & 1.256 & 145 & 3.796 & 6.773 & 23.962 \\
\hline Şanlıurfa & 9.667 & 160 & 3.934 & 28 & 564 & 837 & 5.169 \\
\hline Hatay & 4.990 & 79 & 1.546 & 23 & 552 & 1.112 & 2.892 \\
\hline Trabzon & 5.028 & 58 & 869 & 42 & 1.108 & 1.892 & 3.051 \\
\hline Türkiye & $\mathbf{5 0 8 . 8 5 1}$ & $\mathbf{5 . 6 4 9}$ & $\mathbf{1 1 7 . 5 8 0}$ & $\mathbf{3 . 6 9 1 1}$ & $\mathbf{9 4 . 0 1 6}$ & $\mathbf{1 0 7 . 2 8 4}$ & $\mathbf{2 9 7 . 2 5 5}$
\end{tabular}

Kaynak: İŞKUR, 2018 Yılllk İstatistik Bülteni

Türkiye İş Kurumu (IŞKUR)'un 2018 yılında gerçekleştirdiği İşgücü Piyasası Araştırması raporunda, işverenlere, engellilerin istihdamına yönelik görüşlerini ölçmeye yönelik sorular eklenmiştir. Araştırmada işverenlerin "açı işlerde engelli çalıştırmak isteme durumu" ve "engelli istihdamını arttırmak için önerileri" araştırılmıştır.

Tablo 4. Açık İşlerde Engelli Çalıştırma Durumu, (\%)

\begin{tabular}{lllllll}
\hline & Evet & \multicolumn{3}{c}{ Hayır } & \multicolumn{3}{c}{ Fark etmez } \\
\cline { 2 - 7 } & $\mathbf{2 0 1 8}$ & $\mathbf{2 0 1 9}$ & $\mathbf{2 0 1 8}$ & $\mathbf{2 0 1 9}$ & $\mathbf{2 0 1 8}$ & $\mathbf{2 0 1 9}$ \\
\hline Ankara & 17.5 & 15,6 & 62.0 & 60,9 & 20.6 & 23,4 \\
\hline İstanbul & 14.1 & 17,7 & 57.3 & 53,9 & 28.6 & 28,4 \\
\hline
\end{tabular}




\begin{tabular}{lllllll}
\hline Antalya & 15.7 & 22,5 & 50.3 & 41,9 & 34.0 & 35,6 \\
\hline Şanliurfa & 29.3 & 56,9 & 39.8 & 27,8 & 30.9 & 15,3 \\
\hline Hatay & 4.4 & 3,8 & 76.6 & 62,7 & 19.0 & 33,5 \\
\hline Trabzon & 25.7 & 0,1 & 70.6 & 56,8 & 3.7 & 56,6 \\
\hline Türkiye & $\mathbf{1 5 . 4}$ & $\mathbf{1 6 , 9}$ & $\mathbf{5 9 . 2}$ & $\mathbf{5 6 , 6}$ & $\mathbf{2 5 . 3}$ & $\mathbf{2 6 , 5}$ \\
\hline
\end{tabular}

Kaynak: 2018 ve 2019 İllere Ait İşüucü Piyasası Araştırması (İPA) Raporu

Türkiye genelinde açık işlerde engelli çalıştırma durumuna "evet" cevabını veren işveren oranı 2018 yılında \% 15,4 iken, 2019 yılında bu oran \%16,9'a yükselmiştir. "Hayır" cevabını verenlerin oranı ise 2018 yılında \%59,2 iken, 2019 yılında 3 puan düşerek \%56,3 olarak gerçekleşmiştir. 2019 yılında açık işlerde engelli çalıştırma durumuna "Farketmez" cevabını verenlerin oranı bir önceki yıla göre yaklaşık 1 puan artış göstererek \% 26,5 olmuştur.

Şanlıurfa ilinde açık işlerde engelli çalıştırma durumuna "evet" cevabını veren işveren oranı 2018-2019 yılları arasında yaklaşık iki kat artarak \%56,9'a ulaşmıştır. Trabzon ilinde ise "evet" cevabını veren işveren oranında dikkat çekici bir düşüş yaşanmıştır. 2018 yılında bu oran \%25,7 iken 2019 yılında \%0,01'e düşmüştür.

Tablo 5. Engelli İstihdamını Arttırmak İçin Önerilerin Dağılımı,(\%)

\begin{tabular}{|c|c|c|c|c|c|}
\hline & $\begin{array}{l}\text { Engellilerin } \\
\text { çalışabileceği } \\
\text { destekli } \\
\text { korumalı vb. } \\
\text { işyerlerinin } \\
\text { arttırılması }\end{array}$ & $\begin{array}{l}\text { Engelli } \\
\text { girişimcilere } \\
\text { verilen hibe } \\
\text { çalışmalarının } \\
\text { geliştirilmesi }\end{array}$ & $\begin{array}{l}\text { Engellilere } \\
\text { yönelik uzaktan } \\
\text { çalışma modelleri } \\
\text { geliştirilmesi }\end{array}$ & $\begin{array}{l}\text { Kota } \\
\text { uygulamas } \\
\text { inın revize } \\
\text { edilmesi }\end{array}$ & $\begin{array}{l}\text { Engelli istihdam } \\
\text { fuarları aracılığıyla } \\
\text { işveren ile engelli } \\
\text { danışanların bir } \\
\text { araya getirilmesi }\end{array}$ \\
\hline Ankara & 67.8 & 52.2 & 43.1 & 40.1 & 22.9 \\
\hline İstanbul & 67.5 & 51.9 & 48.5 & 34.9 & 26.6 \\
\hline Antalya & 66.8 & 53.8 & 42.3 & 36.0 & 29.4 \\
\hline Şanlıurfa & 62.6 & 62.5 & 48.4 & 22.5 & 16.7 \\
\hline Hatay & 65.3 & 65.2 & 48.0 & 34.3 & 21.2 \\
\hline Trabzon & 71.5 & 55.7 & 36.7 & 32.8 & 24.5 \\
\hline Türkiye & 67.9 & 56.2 & 43.1 & 40.1 & 22.9 \\
\hline
\end{tabular}

Kaynak: 2018 İşgücü Piyasası Araştırması (IPA) Raporu

İşverenlere göre Türkiye genelinde engelli istihdamının arttırılması konusunda en önemli araç engellilerin çalışabileceği destekli korumalı vb. işyerlerinin arttırılmasıdır. Daha sonra sırasıyla engelli girişimcilere verilen hibe çalışmalarının geliştirilmesi $(\% 56,2)$, engellilere yönelik uzaktan çalışma modelleri geliştirilmesi $(\% 43,1)$ ve kota uygulamasının revize edilmesi $(\% 40,1)$ önerilmektedir. Öneriler arasında en düşük oran engelli istihdam fuarları aracılığıyla işveren ile engelli danışanların bir araya getirilmesidir $(\% 22,9)$. İncelenen illerde de Türkiye geneline benzer bir görünüm ortaya çımaktadır.

\section{İncelenen Belediyelerde Engelli İstihdamına Yönelik Yapılan Düzenlemeler}


Ankara, İstanbul, Antalya, ve 2012 yılında yürürlüğe giren “6360 sayılı On Dört Ilde Büyuikșehir Belediyesi ve Yirmi Yedi Ilçe Kurulması ile Bazı Kanun ve Kanun Huikmünde Kararnamelerde Değsşiklik Yapılmasına Dair Kanun” ile büyükşehir olan Şanlıurfa, Hatay ve Trabzon Büyükşehir Belediyelerinin 2018 yılına ait faaliyet raporları ve internet siteleri incelenerek, engelli bireylerin istihdam edilebilirliklerini arttırmaya ve istihdam etmeye yönelik faaliyetleri incelenmiştir.

Ankara Büyükşehir Belediyesinde Sosyal Hizmet Daire Başkanlığı bünyesinde Engelliler ve Rehabilitasyon Şube Müdürlüğü bulunmaktadır. Belediyede engellilere yönelik Engelliler Hizmet ve Rehabilitasyon Merkezi, Görme Engelliler Eğitim ve Teknoloji Merkezi, Engelliler Lokali ve Tatil kampları hizmetleri yer almaktadır. Engelli hizmetleri engelli vatandaşlara sosyal, kültürel, sağlık, spor, eğitim ve bilişim alanındaki sorunlarına çözüm üretme ve rehabilite ederek topluma kazandırmayı misyon edinmiştir (www.ankara.bel.tr). Görme Engelli Eğitim Ve Teknoloji Merkezinde engelli vatandaşların bilgiye erişmeleri ve mesleki gelişimlerine teknolojik olarak katkıda bulunmaları amaçlanmaktadır. Merkezde ders kitapları ve Kamu Personeli Seçme Sınavı (KPSS) vb. sınav kitapları Braille ve mp3 olarak hazırlanmaktadır. Ankara ili dışındaki görme engelli üyelere de talep etmeleri halinde kitaplar Braille, mp3 ya da mail yoluyla ulaştırılmaktadır. Engelli bireylerin ekonomik özgürluklerini kazanarak topluma ve hayata kolaylıkla adapte olmalarını saglamak amacıyla 30.07.1999 tarih ve 504 sayılı Meclis Kararı ve 12.08.2008 tarih ve 1999 sayılı meclis kararı ile Bahçelievler kapalı pazaryeri içinde Özürlü Ticaret Merkezi faaliyete açılmış ve engelli vatandaşlara ticaret merkezinin içinde ücretsiz olarak stantlar tahsis edilmiştir Ticaret Merkezinde 10 Engelli vatandaşa stant tahsis edilmiştir(Ankara Büyükşehir Belediyesi 2018 Yılı Faaliyet Raporu).

İstanbul Büyükşehir Belediyesinde engellilere yönelik ilk düzenleme 1994 yılında Özürlüler Koordinasyon Merkezi kurulması ile gerçekleşmiştir. Günümüzde ise Sağlık Daire Başkanlığına bağlı Engelliler Müdürlüğü olarak hizmet vermektedir. Engelli bireylerin istihdama katılımının sağlanması için gereken hizmetin verilmesini kendisine misyon edinen Belediyenin Engelliler Müdürlüğüne bağlı 30'a yakın Engelli Merkezi, 9 İrtibat Bürosu ve 2 Engelli Kampı bulunmaktadır (Tınar, 2020, s.16). Zihinsel Engelliler Beceri Kazandırma ve Mesleki Rehabilitasyon Merkezleri ile 17-35 yas, arasında, hafif veya orta düzeyde zihinsel engelliler ile otizmli bireylere; mesleki becerilerinin artırılması ve yeteneklerinin geliştirilmesi amacıyla öz bakım, el ve sosyal becerilerini arttıran rehabilitasyona yönelik egitimler verilmektedir. Mesleki ve Kişisel Gelişim Eğitim Hizmetleri kapsamında tüm engel gruplarındaki bireylere mesleki bilgi ve beceri kazandırarak üretkenliklerinin arttırılması saglanmaktadır. Engellilik durumuna ve bireylerin yeteneklerine göre düzenlenen kurslarda grafik, aşçılık, resim, diksiyon, görme engellilere yönelik bilgisayar kullanımı, E-KPSS, fotoğraf çekimi, tiyatro, müzik vb. çeşitli eğitimler verilerek, başarılı olan bireylere başarıyla tamamlayan bireylere Milli Eğitim Bakanlığı onaylı mesleki sertifika verilmektedir. İstanbul Büyükşehir Belediyesi Engelliler Müdürlüğü (İSEM) bünyesinde hizmet veren Engelli Merkezlerinde Engelli Kamu Personeli Seçme Sınavı (E-KPSS) ve çeşitli sınavlara yönelik hazırlık kursu eğitimleri verilmektedir. İstihdam Destek Hizmetleri ile engelli bireylerin is, hayatına hazırlanması ve engelli bireyin is, bulmasında aracı olunması hedeflenmekte; engelli bireyin nitelikleri ve yetkinlikleri dikkate alınarak kendisine uygun is, olanakları aras,tırılmakta ve işverenlerle temasa geçilmektedir. Engelli bireyler özgeçmiş bilgileri ve fiziksel ve psikososyal özelliklerine uyan açı işlere yönlendirilmektedir (İstanbul Büyükşehir Belediyesi 2018 
Yılı Faaliyet Raporu). Ayrıca engelli vatandaşların işgücü piyasasına katılımının sağlanmasını kolaylaştırmak amacıyla 2016 yılında İstanbul Büyükşehir Belediyesi ve Çalışma ve İş Kurumu (İŞKUR), İstanbul İl Müdürlüğü arasında protokol imzalanmıştır (Tınar, 2020, s.19).

İstanbul Büyükşehir Belediyesi tarafından 1996 yılında kurulan Sanat ve Mesleki Eğitim Kursları (İSMEK) engelli bireylerin de mesleki becerilerini geliştirmeyi ve bireylere işgücü piyasasının talep ettiği nitelikleri kazandırmayı amaçlamaktadır. İSMEK bünyesinde Arnavutköy, Fatih ve Ümraniye ilçesinde olmak üzere üç adet engelli eğitim merkezi bulunmaktadır. Merkezde bilgisayar işletmenliği, blog web sitesi yapımı ve bloggerlik, sepet örücülüğü, turistik ve hediyelik eşya yapımı vb. oluşan otuz farklı branşta kurs bulunmaktadır (www.ismek.ist).

Antalya Büyükşehir Belediyesinde ise Sosyal Hizmet Daire Başkanlığ1 altında Engelli Hizmetleri Şube Müdürlüğü bulunmaktadır. Belediyenin görev ve sorumlulukları arasında engellilere yönelik mesleki ve beceri kazandırma kursu açma ve bu hizmetlerden yararlanmak için liseler, yükseköğretim ve sivil toplum kuruluşları ile işbirliği yapması yer almaktadır (www.antalya.bel.tr). Engelli Hizmetleri Şube Müdürlüğüne bağlı Engelli Hizmet Merkezlerinde engelli bireylerin ve yakınlarının ihtiyaçlarına yönelik kurslar düzenlenmiștir. Bu kapsamda; merkezlerde sesli kütüphane (internet, kitap okuma vb.) yazılı kaynak (Braille çıtı, kitap tarama vb.)hizmetleri sunulmaktadır. Ayrıca merkezin eğitmen kadrosunda görevli personel tarafından el sanatları kursu verilmiştir. Azize Kahraman Halk Eğitim Merkezi işbirliği ile engelli ve engelli yakınlarına yönelik şiş ve tığ örücülüğü, örgü bebek yapımı (amigurumi) kursu açlmıştır.

Engelli bireylerin, başta erişilebilirlik olmak üzere eğitim, sağlık, rehabilitasyon, istihdam v.b. konulara yönelik yaşadıkları sorunlarda; Büyükşehir Belediyesi, ilçe belediyeleri, ilgili kamu kurumları ve STK'ların is, birliği de saglanarak gerekli olan çalışmaların planlanması, programa alınması ve engelli vatandaşlar için uygun hale getirilmesi amacıyla yürütülecek çalışmaları koordine etmek üzere Engelsiz Hizmet Komisyonu oluşturulmuştur. Engelli vatandaşlara ve ailelerine istihdam da dahil olmak üzere çeşitli alanlarda danışmanlık hizmeti verilmektedir. Merkezde kurulan iki adet Mesleki Eğitim Atölyesinde Organize Sanayi Bölgesinde yer alan çeşitli fabrikalar için üretim destek faaliyetleri yapılmıştır (Antalya Büyükşehir Belediyesi 2018 Yılı Faaliyet Raporu).

2012 yılında Büyükşehir statüsü kazanan Şanlıurfa'da Sağlık ve Sosyal Hizmet Daire Başkanlığı bünyesinde Engelliler Şube Müdürlüğü bulunmaktadır. Belediyede engelli vatandaşların sosyal hayata erişimlerini sağlamak, özgüvenlerini artırmak mesleki eğitimle üretime katkı sunmalarını sağlamak amacıyla Türkiye'nin en kapsamlı merkezlerinden biri olan Engelliler Koordinasyon ve Yaşam Merkezi yapılmıştır (Şanlıurfa Büyükşehir Belediyesi 2018 Yılı Faaliyet Raporu). Her engel grubuna hizmet verebilecek şekilde tasarlanan merkezde engel gruplarına göre mesleki atölyeler ve kurslar verilmektedir. Örneğin bakır rölyef işlemeciliği kursu, deri sanat atölyesi, el sanatları atölyesi, ebru sanat kursu, ahşap oymacılığ bunlardan bazılarıdır. Açılan giyim üretim teknolojileri atölyesi ile meslek sahibi olmaları ve aile ekonomisine katkı sağlamaları amaçlanmaktadır. Bilgisayar kursu ile engelli bireylerin bilgiye erişimleri sağlanmakta, iletişim teknolojileri geliştirilmektedir (www.sanliurfa.bel.tr) . 
Trabzon Büyükşehir belediyesinde ise engellilere yönelik hizmetler Sosyal Hizmetler Şube Müdürlüğü tarafından gerçekleştirilmektedir. Belediyede, engelli bireylerin talepleri doğrultusundan belediye bünyesinde yer alan Mesleki ve Eğitim Şube Müdürlüğü tarafından kurslar gerçekleştirilmekte ve engellilere yönelik projelere destek verilmektedir (www.trabzon.bel.tr). Hatay Büyükşehir Belediyesinde ise Engelli Koordinasyon Merkezi kuruluş çalışmaları devam etmektedir(www.hatay.bel.tr). Dolayısıyla Hatay ve Trabzon Büyükşehir belediyesinin incelenen dönemde doğrudan engellilere yönelik kurumsal yapılarının olmadığı, engellilere yönelik faaliyetlerini sosyal hizmet birimi çatısı altında gerçekleştirdikleri görülmektedir. Ankara, İstanbul, Antalya ve Şanlıurfa'da mesleki eğitim faaliyetleri ile engellilerin istihdama katılmalarını sağlanmaya çalışılmaktadır.

\section{Sonuç}

Bu çalışmada 2012 yılında büyükşehir belediyesi statüsü kazanan ve en kalabalık nüfusa sahip olan Hatay, Trabzon ve Şanlıurfa Büyükşehir Belediyesi ile uzun süredir büyükşehir belediyesi statüsünde olan Ankara, İstanbul ve Antalya belediyelerinin engelli istihdamina ilişkin yaklaşımları 2018 yılına ait faaliyet raporları ve belediyeye ait internet siteleri aracılığıla incelenmiştir. Buna göre her bir belediyenin engellilerin ekonomik hayata katılımı için fırsat eşitliğini sağlamaya yönelik hizmetleri misyon görülmektedir.

Diğer yandan engellilerin istihdama erişimlerine yönelik sağlanan hizmetlerin "kurumsal yapılanma" durumuna bağlı olarak farklılıklar taşıdığını belirtmek mümkündür. Bir diğer ifade ile engelliler şube müdürlüğü veya engelliler daire başkanlığının olduğu büyükşehir belediyelerinin engelli istihdamına yönelik daha sistematik ve kapsamlı faaliyetlerde bulunduğunu gözlenmiştir. Söz konusu belediyeler engellilik durumuna özel mesleki eğitim kursları, mesleki atölyeler ve akademik eğitim aracılığıyla engellilerin istihdam edilebilirliklerini arttırmaya yönelik sürekli hizmet sağlamaktadır.

\section{Kaynakça}

Aile ve Sosyal Politikalar Bakanlığı. (ASPB). (2015). Kamuda Engelli İstihdamının Analizi, T.C. Aile ve Sosyal Politikalar Bakanlı̆ı̆ Engelli ve Yaşsı Hizmetleri Genel Müdürlügüư Yayınları, Ankara.

Aile, Çalışma ve Sosyal Hizmetler Bakanlığı (2020). Engelli ve Yaşlı İstatistik Bülteni, Mart 2020.

Akdoğan, Yalçın (2002), Ulusal Soruna Yerel Çözüm: Sosyal Belediyecilik” Eminönü Bülteni, Şubat Sayısı.

Altan, Ömer, Zühtü (2006), Sosyal Politika Dersleri, Anadolu Üniversitesi Yayınları, Eskişehir. Ankara Büyükşehir Belediyesi Faaliyet Raporu, 2018.

Antalya Büyükşehir Belediyesi Faaliyet Raporu, 2018.

Başbuğ, Aydın (2013), Sosyal Hukuk Hukukun Toplumsal Temelleri, A kitap, Ankara.

Candan, Ayşen ve Yılmaz, Volkan (2012), Türkiye'de Eşitsizlikler, Bilnet Matbaacılık, İstanbul. 
Göregenli, Melek (2012), Ayrımcılığın Meşrulaştırılması, s.61-73. Ayrımcılık Çok Boyutlu Yaklaşımlar Kitabı İçinde, der. (Kenan Çayır ve Müge Ayan Ceyhan), İstanbul Bilgi Üniversitesi Yayınları.

Göregenli, Melek (2008). Ayrımcılık ve İnsan Hakları Aralık 2007 Çalışma Toplantısı Raporu. Gül, İdil Işıl ve Karan, Ulaş (2011), Ayrımcılık Yasağ1 Kavram, Hukuk, İzleme ve Belgeleme, (ed. Burcu Yeşiladalı ve Gökçeçiçek Ayata) İnsan Hakları Hukuku Çalışmaları, İstanbul Bilgi Üniversitesi Yayınları, İstanbul.

Güven, Sami (1995), Sosyal Politikanın Temelleri, Ezgi Kitabevi, Bursa.

Hatay Büyükşehir Belediyesi Faaliyet Raporu, 2018.

İstanbul Büyükşehir Belediyesi Faaliyet Raporu, 2018.

Keleş, Sümeyra (2008), Türkiye'de Sosyal Belediyecilik Uygulamaları ve Ankara Büyükşehir Belediyesi, Yüksek Lisans Tezi, Afyonkarahisar.

Kesgin, Bedrettin (2014), Engellilere Yönelik Yerel Sosyal Politikalar, Çağdaş Yerel Yönetimler, cilt 23 , sayı 4 , ss. $1-15$.

Koray, M. (2000). Sosyal Politika, Ezgi Kitabevi, Bursa.

Koray, Meryem ve Temiz, Hasan Ejder (2014), Merkezi Yönetimle İlişkiler, Kısıtlar ve Harcamalar Çerçevesinde Sosyal Belediyecilik ve Dört Büyükşehir Belediyesi Açısından Uygulamalar, Çalışma ve Toplum, 2014/3, syf. 11-60.

Köten, Esra ve Erdoğan, Barış (2014), Engelli Gençler, Sosyal Dışlanma ve Internet, İstanbul Gelişim Üniversitesi Yayınları, İstanbul.

Oliver, Michael (1990), Disability and Rise of Capitalism, Politics of Disablement, Londra: Macmillan, s.25-42, Der D.Bezmez., S.Yardımcı ve Y.Şentürk, Sakatlık Çalışmaları Sosyal Bilimlerden Bakmak, Koç Üniversitesi Yayınları, 2011, s.209-227.

Orhan, Serdar (2013), Türkiye'de Özürlü Dostu İstihdam Politikaları (Durum Analizi ve Öneriler). Çalışma ve Sosyal Güvenlik Eğitim ve Araştırma Merkezi Yayınları, Yayın No 35.

Özdemir, Süleyman (2007). Küreselleşme Sürecinde Refah Devleti, İstanbul Ticaret Odası Yayınları, Yayın No: 2007-57.İstanbul.

Schiner, Kay (2001), A Disability Studies Perspective on Employment Issues and Policies for Disabled People: An International View, Handbook of Disabilty Studies içinde der. G.L. Albercht, K.D. Selman ve M. Bury, Londre ss.624-662. Der D.Bezmez., S.Yardımcı ve Y.Şentürk, Sakatlık Çalışmaları Sosyal Bilimlerden Bakmak, Koç Üniversitesi Yayınları, 2011, s.269-299.

Seyyar, Ali (2008), Sosyal Siyaset Ekseninde Yerel Ozürluiler Politikası.http://www.sosyalsiyaset.net/documents/yerel_ozurluler_politikasi.htm, erişim tarihi: 13.03.2019

Şanlıurfa Büyükşehir Belediyesi Faaliyet Raporu, 2018.

Şişman, Yener (2011), Türkiye'de Özürlülere Yönelik Yasal Düzenlemeler, Sosyal Siyaset Konferanslarl, sayı 60, ss. 169-221.

TBMM. (Türkiye Büyük Millet Meclisi). (2013). Engelli Hakları Komisyon Raporu.

Tinar, Y. (2020). Yerel Yönetimlerce Engellilere Sunulan İstihdam Hizmetleri: İstanbul Büyuikşehir Belediyesi Engelliler Müdürlügü Örneği. Sosyal Siyaset Konferansları Dergisi. Advanced online publication. https://doi.org/10.26650/ jspc.2020.78.0011

T.C. Başbakanlık Özürlüler İdaresi Başkanlığı. (2005). 2.Özürlüler Şurası Yerel Yönetimler ve Özürlüler Şura Kararları, NUROL matbacılık, Ankara. 
T.C. Başbakanlık Özürlüler İdare Başkanlığı, (2002). Toplum Özürlülüğü Nasıl Anlıyor Araştırmasi.

Thomas, Carol (2002), Disability Theory: Key Ideas, Issues and Thinkers, Disability Studies Today içinde der. C.Barnes, M.Oliver ve Len Barton, Oxford Polity, s.38-57. Der D.Bezmez., S.Yardımcı ve Y.Şentürk, Sakatlık Çalışmaları Sosyal Bilimlerden Bakmak, Koç Üniversitesi Yayınları, 2011, s.31-51.

TÜİK. (Türkiye İstatistik Kurumu). (2018). Türkiye Geneli İşgücü Piyasası Araştırması İPA Sonuçları.

Trabzon Büyükşehir Belediyesi Faaliyet Raporu, 2018.

WHO. (Dünya Sağlık Örgütü). Dünya Engellilik Raporu, 2011.

Yilmaz, Volkan (2010), The Political Economy of Disability In Turkey's Welfare Regime, Master of Arts, Boğaziçi University, İstanbul. 